\title{
Pesticidal Compatibility against Yellow Stem Borer and Sheath Blight in kharif and Rabi Rice
}

\author{
Chirasree Gangopadhyay and Sitesh Chatterjee*
}

Rice Research Station, Government of West Bengal, Chinsurah (R.S.), Hooghly, West Bengal, India

*Corresponding author

\begin{abstract}
A B S T R A C T
Keywords

Rice, Pesticide compatibility, Flubendiamide + buprofezin,

Hexaconazole, Yellow stem borer, Sheath blight, Spider, Coccinellid

Article Info

Accepted:

04 October 2020

Available Online:

10 November 2020

A field experiment was carried out at Rice Research Station, Chinsurah, Hooghly during kharif, 2013 and boro, 2013-14 to evaluate the compatibility of selected insecticides with fungicides against yellow stem borer (YSB) and sheath blight (ShB). The trial included nine treatments consisting of insecticides, pre-mix flubendiamide + buprofezin and triazophos and fungicide, hexaconazole and tricyclazole which were applied alone as individual treatment and in four possible combination treatment with untreated control. The experiment was laid in RBD with three replications. The results revealed that during kharif, flubendiamide + buprofezin had performed best against YSB. Whereas, in boro the combination of flubendiamide + buprofezin with tricyclazole was the best against dead heart. Whereas, flubendiamide + buprofezin alone had shown best result against white ear head. Low ShB severity was recorded in pre-mix flubendiamide + buprofezin along with hexaconazole treatment both in kharif and boro. In both the seasons, the highest population of spiders and coccinellids was recorded in flubendiamide + buprofezin treatment. No adverse impact on the efficacy of the combination of flubendiamide + buprofezin and triazophos with tricyclazole and hexaconazole against YSB and ShB confirming the compatibility between them when used as tank mix in the field condition.
\end{abstract}

\section{Introduction}

Rice in West Bengal is considered as the dominant food crop and is grown in all six agro-climatic zones of the state under diversified situations such as upland, rainfed shallow, semideep and deep lowland and finally irrigated conditions. The state, West Bengal ranks second in area $(5,386,000 \mathrm{ha})$ and first in production $(14,771,0000$ tons) of rice in India (Chatterjee et al., 2017). The major constrains for low productivity of rice in India is the losses due to insect pests and diseases. Rice stem borers are the principal pests responsible for economic crop loss under field conditions (Heinrichs et al., 2017). Over 90 per cent of the borer populations were occupied by the $S$. incertulas in kharif rice from seedling to maturity stage in new alluvial zone of West Bengal (Chatterjee et al., 2017). The yield loss due to S. incertulas was estimated to be approximately 10-60 percent in India (Panda, et al., 1976; Pasalu, et al., 2005). Sheath blight, a soil-borne 
fungal disease (Rhizoctonia solani Kuhn) causing $25 \%$ yield losses and considered important next to blast disease of rice crop. This disease is an important constraint in intensified rice production systems. A critical analysis of the gap between the potential and actual rice yields across the nation revealed several factors act as yield constraints (Chatterjee et al., 2016). To combat this situation the application of combination of suitable insecticides and fungicides as tank mix is economic, time saving and feasible management practice. Therefore, it is essential to evaluate compatibility of insecticides and fungicides against insect pests and diseases of rice. The systematic efforts for evaluation of compatibility of insecticides and fungicides were done at the Directorate of Rice Research, Hyderabad (Bhatnagar, 2004; Bhuvaneshwari and Krishnam, 2013). Keeping this in view, the study was undertaken to evaluate the compatibility of one new insecticide combination (flubendiamide+buprofezin) and other groups of insecticides and fungicides based on their efficacy against rice stem borer and sheath blight diseases of rice.

\section{Materials and Methods}

The field experiments have been conducted at Rice Research Station, Chinsurah, West Bengal in randomized block design with three replications during kharif 2013 and boro 2013-14. The plot size was $5 \times 3 \mathrm{~m}^{2}$ with spacing of $20 \times 15 \mathrm{~cm}^{2}$ and $1.0 \mathrm{~m}$ replication border and $0.5 \mathrm{~m}$ treatment border between the plots. The experimental plots were separated by raising bunds of about $15 \mathrm{~cm}$ height all around each plot. The rice varieties, Swarna (MTU 7029) in kharif and Khitish (IET 4094) in boro were sown for the present study. Twenty five days old seedlings in kharif during July last week and forty days old seedlings in boro during January last week were transplanted. The crops were raised adopting a standard package of practices with fertilizer dose @ $\mathrm{N}: \mathrm{P}_{2} \mathrm{O}_{5}: \mathrm{K}_{2} \mathrm{O}:: 80: 40: 40 \mathrm{~kg} \mathrm{ha}^{-1}$. The treatments included two insecticides, viz. flubendiamide $4 \%$ + buprofezin 20\% SC @ $1.75 \mathrm{ml} \mathrm{l}^{-1}$ $\left(35+175 \mathrm{~g}\right.$ a.i. $\left.\mathrm{ha}^{-1}\right)$ and triazophos 40 EC @ $1.5 \mathrm{ml} \mathrm{l}^{-1}\left(300 \mathrm{~g}\right.$ a.i. ha $\left.{ }^{-1}\right)$ and two fungicides, viz. hexaconazole 5 SC @ $2.0 \mathrm{ml} \mathrm{l}^{-1}$ (50 g a.i. $\mathrm{ha}^{-1}$ ) and tricyclazole 75 WP @ $0.6 \mathrm{~g} \mathrm{l}^{-1}$ (225 $\mathrm{g}$ a.i. $\mathrm{ha}^{-1}$ ) and four possible combinations of these four pesticides besides untreated control (Table 1). High volume spray @ 500 litres of water for one hectare area was considered for spraying of each treatment. Two spraying schedule of each treatment was conducted at 15 and 45 days after transplanting (DAT). The application of pesticides on 15 DAT can manage the disease and insect-pest attack at tillering stage whereas application of pesticides on 45 DAT can control the pests attack at reproductive stage. The observations were made on dead heart at maximum tillering stage on 45 DAT and before harvest for white ear damage of yellow stem borer and per cent sheath blight incidence. The stratified random sampling from ten hills was followed to record the infestation of yellow stem borer. The infestation of sheath blight was recorded from two sampling units of one square meter each fixed in each plot at random at vegetative stage at 80 DAT. The per cent severity (as per cent area of leaf affected) of sheath blight (Rhizoctonia solani) was calculated (IRRI, 2013). Symptoms include oval or ellipsoidal greenish-gray lesions, usually 1-3 cm long, on the leaf sheath, initially just above the soil or water level in conventionally flooded rice fields. Under favourable conditions, initial lesions multiply and expand to the upper part of the sheaths and leaves, and then spread to neighbouring tillers of different hills (transplanted rice) or plants (direct-seeded rice). Lesions on the leaves usually have irregular lesions, often with gray-white centers and brown margins as they grow 
older. The infection may even reach to panicle causing grain blight) per cent of disease covered of height of each hill sampled (Manandhar et al., 2016). The number of natural enemies viz. spiders (Tetragnatha sp., Argiope sp., Oxyopes sp., Lycosa sp., Phidippus sp.) and coccinellid (Chilomenes sexmaculatus, Coccinella sp., Harmonia sp., Micraspis sp.) from five hills of each plot were noticed at 45 DAT. Harvesting was done by the end of November in kharif and during April for boro crop. The grain yield per plot was converted into $\mathrm{kg} \mathrm{ha}^{-1}$. The yield data was recorded by excluding two border rows from all sides for each plot separately. The per cent infestation of YSB and sheath blight were converted into angular transformed values and thereafter the paddy yield and infestation data were compared for significance using critical difference at 0.05 probability level.

\section{Results and Discussion}

The dead heart infestation during kharif 2013 and boro 2013-14 varied from 0.64 to $17.60 \%$ $\mathrm{DH}$ and 11.51 to $21.82 \% \mathrm{DH}$ respectively (Table 2 and 3). The results revealed that all the insecticidal treatments alone or in combination with fungicides were significantly superior to untreated control and fungicidal treatments alone. However, the treatment, pre-mix of flubendiamide + buprofezin alone was found most effective with $0.64 \%$ average dead heart infestation followed by the combination treatment of premix flubendiamide + buprofezin and hexaconazole $(1.34 \% \mathrm{DH})$, in comparison to $17.60 \% \mathrm{DH}$ in untreated control during kharif 2013 (Table 2). During the season, the lowest white ear head infestation $(0.84 \%$ WE) was recorded when flubendiamide + buprofezin was applied followed by tank mix application of pre-mix flubendiamide + buprofezin and tricyclazole $(2.76 \% \mathrm{WE})$. The stem borer infestation was found highest in the untreated control plots $(19.52 \%$ WE). Phytotoxicity symptoms like scorching effect, drying of leaves and stems or in any, were not observed in any treatment when pesticides were applied in combination. The most effective treatment was the tank mix of pre-mix flubendiamide + buprofezin and hexaconazole (3.30\% ShB) against sheath blight in Swarna variety during kharif season followed by hexaconazole (3.69\% ShB) alone compared to the control plots (17.88\% ShB). In kharif, the maximum population of spiders and coccinellids was noticed in pre-mix flubendiamide + buprofezin (0.79 spider hill $^{-1}$ and 0.43 coccinellid hill ${ }^{-1}$ ) treated plots followed by untreated control (0.77 spider hill $\left.^{-1}\right)$ and tricyclazole treatment $\left(0.44\right.$ coccinellid hill $\left.{ }^{-1}\right)$, respectively (Table 4). Highest paddy yield of Swarna variety in kharif was obtained from tank mix of pre-mix flubendiamide + buprofezin and hexaconazole (4670 kg ha ${ }^{-1}$ ) followed by pre-mix flubendiamide + buprofezin (4503 kg ha ${ }^{-1}$ ) in comparison to control (3613 kg ha-1) (Table 2).

During boro 2013-14, the results revealed that all the insecticidal treatments alone or in combination with fungicides were significantly superior to untreated control and fungicidal treatments alone. However, the most effective treatment against dead heart was observed in the combination of pre-mix flubendiamide + buprofezin and tricyclazole $(11.02 \% \mathrm{DH})$ followed by pre-mix flubendiamide + buprofezin alone $(11.51 \%$ $\mathrm{DH})$ compared to the hexaconazole treated plots $(21.82 \% \mathrm{DH})$ and untreated control $(17.61 \% \mathrm{DH})$. Whereas in later stage, pre-mix of flubendiamide + buprofezin alone $(6.90 \%$ WE) showed the best performance against white head, followed by combination of premix flubendiamide + buprofezin with tricyclazole $(7.14 \% \mathrm{WE})$ in comparison to the untreated plots $(26.40 \%$ WE). No phytotoxicity symptom was observed in any treatment when pesticides were applied in combination. 
Table.1 Treatments details with pesticidal doses

\begin{tabular}{|c|l|c|c|}
\hline Treatments & \multicolumn{1}{|c|}{$\begin{array}{c}\text { Applied pesticides } \\
\text { (Chemical name) }\end{array}$} & in g a.i. ha & Dose \\
\hline $\mathbf{T}_{\mathbf{1}}$ & $\begin{array}{l}\text { Flubendiamide 4\% } \\
\text { buprofezin 20\% SC }\end{array}$ & $35+175$ & 1.75 \\
\hline $\mathbf{T}_{\mathbf{2}}$ & Triazophos 40\% EC & & 1.5 \\
\hline $\mathbf{T}_{\mathbf{3}}$ & Hexaconazole 5\% SC & 300 & 2.0 \\
\hline $\mathbf{T}_{\mathbf{4}}$ & Tricyclazole 75\% WP & 50 & 0.6 \\
\hline $\mathbf{T}_{\mathbf{5}}$ & Tank mix of $\mathrm{T}_{1}+\mathrm{T}_{3}$ & 225 & $1.75+2.0$ \\
\hline $\mathbf{T}_{\mathbf{6}}$ & Tank mix of $\mathrm{T}_{1}+\mathrm{T}_{4}$ & - & $1.75+0.6$ \\
\hline $\mathbf{T}_{\mathbf{7}}$ & Tank mix of $\mathrm{T}_{2}+\mathrm{T}_{3}$ & - & $1.5+2.0$ \\
\hline $\mathbf{T}_{\mathbf{8}}$ & Tank mix of $\mathrm{T}_{2}+\mathrm{T}_{4}$ & - & $1.5+0.6$ \\
\hline $\mathbf{T}_{\mathbf{9}}$ & Untreated control & - & - \\
\hline
\end{tabular}

Table.2 Efficacy of different pesticides and their combinations against insect pest and disease of rice (cv. Swarna) during kharif, 2013

\begin{tabular}{|c|c|c|c|c|}
\hline \multirow[t]{2}{*}{ Treatments } & \multicolumn{2}{|c|}{$\begin{array}{l}\text { Yellow stem borer } \\
\text { Damage }\end{array}$} & \multirow[t]{2}{*}{$\begin{array}{l}\text { Sheath } \\
\text { blight \% }\end{array}$} & \multirow{2}{*}{$\begin{array}{c}\text { Paddy } \\
\text { yield (kg } \\
\left.\text { ha }^{1}\right)\end{array}$} \\
\hline & DH\% & WE\% & & \\
\hline $\begin{array}{l}\mathrm{T}_{1}=\text { Flubendiamide } 4 \%+ \\
\text { buprofezin } 20 \%\end{array}$ & $\begin{array}{c}0.64 \\
(4.59)\end{array}$ & $\begin{array}{c}0.84 \\
(5.26)\end{array}$ & $\begin{array}{c}17.69 \\
(24.84)\end{array}$ & 4503 \\
\hline$T_{2}=$ Triazophos $40 \%$ & $\begin{array}{l}2.48 \\
(9.06)\end{array}$ & $\begin{array}{c}4.52 \\
(12.27)\end{array}$ & $\begin{array}{c}18.41 \\
(25.36)\end{array}$ & 4017 \\
\hline $\mathrm{T}_{3}=$ Hexaconazole $5 \% \mathrm{SC}$ & $\begin{array}{c}14.87 \\
(22.67)\end{array}$ & $\begin{array}{c}15.19 \\
(22.93)\end{array}$ & $\begin{array}{c}3.69 \\
(11.02)\end{array}$ & 3950 \\
\hline$T_{4}=$ Tricyclazole $75 \%$ & $\begin{array}{c}17.14 \\
(24.45)\end{array}$ & $\begin{array}{c}9.34 \\
(17.79)\end{array}$ & $\begin{array}{c}17.37 \\
(24.58)\end{array}$ & 3840 \\
\hline $\mathbf{T}_{5}=\left(\mathbf{T}_{1}+\mathbf{T}_{3}\right)$ & $\begin{array}{c}1.34 \\
(6.64)\end{array}$ & $\begin{array}{c}2.90 \\
(9.80)\end{array}$ & $\begin{array}{c}3.30 \\
(10.33)\end{array}$ & 4670 \\
\hline $\mathbf{T}_{6}=\left(\mathbf{T}_{1}+\mathbf{T}_{4}\right)$ & $\begin{array}{c}1.68 \\
(7.44)\end{array}$ & $\begin{array}{c}2.76 \\
(9.56)\end{array}$ & $\begin{array}{c}18.05 \\
(25.11)\end{array}$ & 4400 \\
\hline $\mathbf{T}_{7}=\left(\mathbf{T}_{2}+\mathbf{T}_{3}\right)$ & $\begin{array}{c}7.41 \\
(15.79)\end{array}$ & $\begin{array}{c}7.75 \\
(16.16)\end{array}$ & $\begin{array}{c}3.81 \\
(11.15)\end{array}$ & 4377 \\
\hline$T_{8}=\left(T_{2}+T_{4}\right)$ & $\begin{array}{c}3.97 \\
(11.49)\end{array}$ & $\begin{array}{c}7.51 \\
(15.90)\end{array}$ & $\begin{array}{c}16.63 \\
(24.04)\end{array}$ & 4343 \\
\hline $\mathbf{T}_{9}=$ Untreated control & $\begin{array}{c}17.60 \\
(24.79)\end{array}$ & $\begin{array}{c}19.52 \\
(26.21)\end{array}$ & $\begin{array}{c}17.88 \\
(24.98)\end{array}$ & 3613 \\
\hline SEm \pm & 1.89 & 1.94 & 1.04 & 79.74 \\
\hline CD 0.05 & 5.73 & 5.86 & 3.13 & 241.12 \\
\hline
\end{tabular}

Figures in the parenthesis are angular transformed values 
Table.3 Efficacy of different pesticides and their combinations against insect pest and disease of rice (cv. Khitish) during boro, 2013-14

\begin{tabular}{|c|c|c|c|c|}
\hline \multirow[t]{2}{*}{ Treatments } & \multicolumn{2}{|c|}{$\begin{array}{l}\text { Yellow stem borer } \\
\text { Damage }\end{array}$} & \multirow[t]{2}{*}{$\begin{array}{l}\text { Sheath } \\
\text { blight \% }\end{array}$} & \multirow[t]{2}{*}{$\begin{array}{c}\text { Paddy yield (kg } \\
\left.\text { ha }^{1}\right)\end{array}$} \\
\hline & DH\% & WE\% & & \\
\hline $\begin{array}{l}\mathrm{T}_{1}=\text { Flubendiamide } 4 \%+ \\
\text { buprofezin } 20 \%\end{array}$ & $\begin{array}{l}11.51 \\
(19.82)\end{array}$ & $\begin{array}{c}6.90 \\
(15.22)\end{array}$ & $\begin{array}{c}0.75 \\
(4.95)\end{array}$ & 4377 \\
\hline$T_{2}=$ Triazophos $40 \%$ & $\begin{array}{l}15.01 \\
(22.78)\end{array}$ & $\begin{array}{c}9.14 \\
(17.57)\end{array}$ & $\begin{array}{c}0.86 \\
(5.32)\end{array}$ & 4190 \\
\hline $\mathrm{T}_{3}=$ Hexaconazole $5 \% \mathrm{SC}$ & $\begin{array}{l}21.82 \\
(27.82)\end{array}$ & $\begin{array}{l}15.68 \\
(23.29)\end{array}$ & $\begin{array}{c}0.27 \\
(2.96)\end{array}$ & 3810 \\
\hline$T_{4}=$ Tricyclazole $75 \%$ & $\begin{array}{l}18.80 \\
(25.69)\end{array}$ & $\begin{array}{l}12.60 \\
(20.78)\end{array}$ & $\begin{array}{c}0.79 \\
(5.09)\end{array}$ & 3713 \\
\hline$T_{5}=\left(T_{1}+T_{3}\right)$ & $\begin{array}{l}13.53 \\
(21.57)\end{array}$ & $\begin{array}{c}8.15 \\
(16.59)\end{array}$ & $\begin{array}{c}0.25 \\
(2.35)\end{array}$ & 4533 \\
\hline$T_{6}=\left(T_{1}+T_{4}\right)$ & $\begin{array}{c}11.02 \\
(19.36)\end{array}$ & $\begin{array}{c}7.14 \\
(15.47)\end{array}$ & $\begin{array}{c}0.82 \\
(5.12)\end{array}$ & 4407 \\
\hline $\mathbf{T}_{7}=\left(\mathbf{T}_{2}+\mathbf{T}_{3}\right)$ & $\begin{array}{c}15.04 \\
(22.79)\end{array}$ & $\begin{array}{c}11.43 \\
(19.74)\end{array}$ & $\begin{array}{c}0.27 \\
(2.96)\end{array}$ & 4247 \\
\hline $\mathbf{T}_{8}=\left(\mathbf{T}_{2}+\mathbf{T}_{4}\right)$ & $\begin{array}{l}12.73 \\
(20.87)\end{array}$ & $\begin{array}{l}10.61 \\
(18.99)\end{array}$ & $\begin{array}{c}0.86 \\
(5.33)\end{array}$ & 4120 \\
\hline $\mathbf{T}_{9}=$ Untreated control & $\begin{array}{l}17.61 \\
(24.79)\end{array}$ & $\begin{array}{l}26.40 \\
(30.91)\end{array}$ & $\begin{array}{c}0.89 \\
(5.42)\end{array}$ & 3443 \\
\hline SEm \pm & 1.50 & 2.30 & 0.42 & 75.27 \\
\hline CD 0.05 & 4.54 & 6.95 & 1.27 & 27.59 \\
\hline
\end{tabular}

Figures in the parenthesis are angular transformed values

Table.4 Efficacy of different pesticides on natural enemies of rice during kharif, 2013 (cv. Swarna) and boro, 2013-14 (cv. Khitish)

\begin{tabular}{|c|c|c|c|c|}
\hline \multirow[t]{2}{*}{ Treatments } & \multicolumn{2}{|c|}{ Kharif 2013} & \multicolumn{2}{|c|}{ Boro 2013-14 } \\
\hline & $\begin{array}{l}\text { Spider } \\
\text { hill }^{-1}\end{array}$ & $\begin{array}{l}\text { Coccinellid } \\
\text { hill }^{-1}\end{array}$ & $\begin{array}{l}\text { Spider } \\
\text { hill }^{-1}\end{array}$ & $\begin{array}{c}\text { Coccinellid } \\
\text { hill }^{-1}\end{array}$ \\
\hline $\begin{array}{l}T_{1}=\text { Flubendiamide } 4 \%+ \\
\text { buprofezin } 20 \%\end{array}$ & 0.79 & 0.43 & 0.45 & 0.40 \\
\hline$T_{2}=$ Triazophos $40 \%$ & 0.14 & 0.11 & 0.07 & 0.05 \\
\hline $\mathrm{T}_{3}=$ Hexaconazole $5 \% \mathrm{SC}$ & 0.58 & 0.40 & 0.43 & 0.36 \\
\hline $\mathbf{T}_{4}=$ Tricyclazole $75 \%$ & 0.71 & 0.44 & 0.40 & 0.33 \\
\hline$T_{5}=\left(T_{1}+T_{3}\right)$ & 0.72 & 0.41 & 0.43 & 0.39 \\
\hline$T_{6}=\left(T_{1}+T_{4}\right)$ & 0.75 & 0.36 & 0.36 & 0.40 \\
\hline $\mathbf{T}_{7}=\left(\mathbf{T}_{2}+\mathbf{T}_{3}\right)$ & 0.13 & 0.09 & 0.05 & 0.04 \\
\hline$T_{8}=\left(T_{2}+T_{4}\right)$ & 0.13 & 0.09 & 0.07 & 0.07 \\
\hline $\mathbf{T}_{9}=$ Untreated control & 0.77 & 0.41 & 0.39 & 0.44 \\
\hline SEm \pm & 0.06 & 0.04 & 0.05 & 0.04 \\
\hline CD 0.05 & 0.12 & 0.11 & 0.14 & 0.11 \\
\hline
\end{tabular}


Fig.1 Pesticidal efficacy against yellow stem borer and sheath blight in rice during kharif and boro

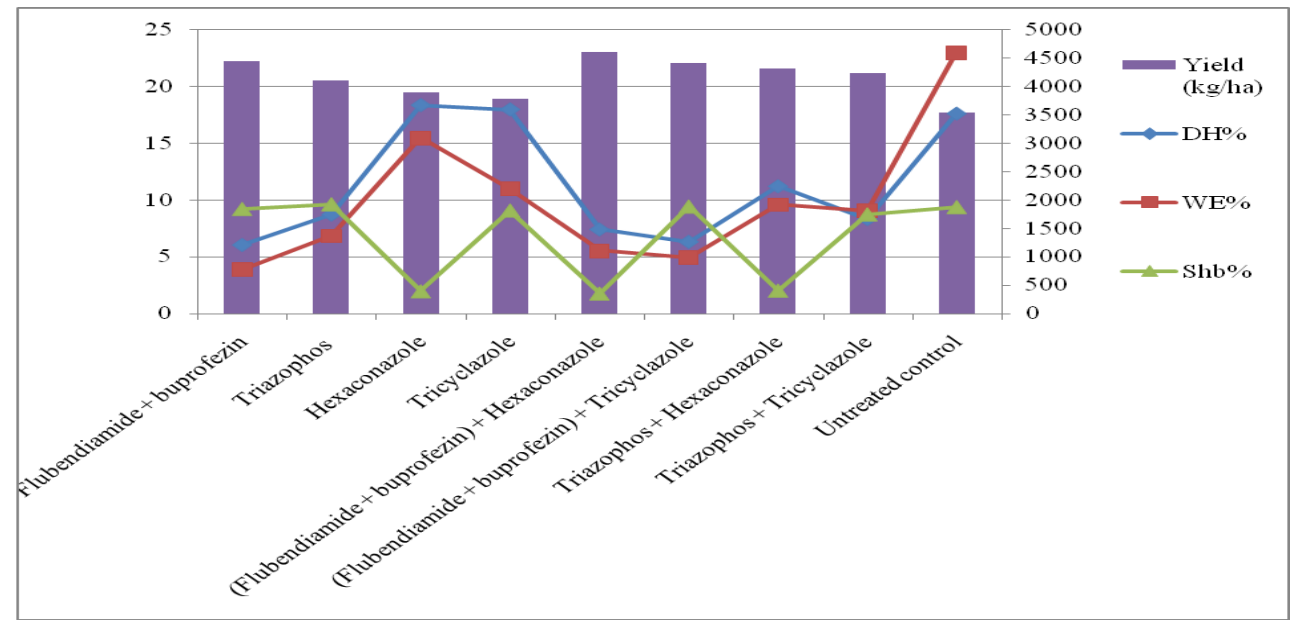

During boro, the combination of pre-mix flubendiamide + buprofezin and hexaconazole $(0.25 \% \mathrm{ShB})$ provided best performance against sheath blight in Khitish variety followed by both the treatments of hexaconazole alone and the combination of triazophos with hexaconazole $(0.27 \% \mathrm{ShB})$. Highest population of spiders and coccinellids was recorded in pre-mix flubendiamide + buprofezin treatment $\left(0.45\right.$ spider hills $\left.^{-1}\right)$ and control plots $\left(0.44\right.$ coccinellid hill $\left.^{-1}\right)$, respectively followed by hexaconazole alone $\left(0.43\right.$ spider hill $\left.^{-1}\right)$ and both the treatments of pre-mix flubendiamide + buprofezin and tank mix of pre-mix flubendiamide + buprofezin and tricyclazole $\left(0.40\right.$ coccinellid hill $\left.{ }^{-1}\right)$, respectively (Table 4). Highest paddy yield of Khitish variety in boro was obtained from combined insecticidal treatment of pre-mix flubendiamide + buprofezin with hexaconazole (4533 $\mathrm{kg} \mathrm{ha}^{-1}$ ) followed by tank mix of pre-mix flubendiamide + buprofezin and tricyclazole (4407 $\mathrm{kg} \mathrm{ha}^{-1}$ ) in comparison to control (3443 $\mathrm{kg} \mathrm{ha}^{-1}$ ) (Table 3).

The mean values of both the seasons that the lowest dead heart was observed in pre-mix of flubendiamide + buprofezin $(6.08 \% \mathrm{DH})$ followed by tank mix of pre-mix flubendiamide + buprofezin and tricyclazole combination $(6.35 \% \mathrm{DH})$ and in the later stage the minimum white head damage was recorded in pre-mix flubendiamide + buprofezin $(3.87 \% \mathrm{WE})$ followed by pre-mix flubendiamide + buprofezin and hexaconazole combination $(5.53 \%$ WE) (Fig. 1). In case of sheath blight, tank mix of flubendiamide + buprofezin and hexaconazole $(1.18 \% \mathrm{ShB})$ treatment was found best followed by hexaconazole alone $(1.98 \% \mathrm{ShB})$. Highest yield was obtained from the plots treated with combination of pre-mix flubendiamide + buprofezin and hexaconazole (4602 $\mathrm{kg} \mathrm{ha}^{1}$ ) followed by pre-mix flubendiamide + buprofezin $\left(4440 \mathrm{~kg} \mathrm{ha}^{-1}\right)$.

The results of this experiment have close proximity with the findings of Prasad et al., (2015) who found that the combination of pre-mix flubendiamide + buprofezin and tricyclazole as tank mix was most effective against stem borer with $3.22 \%$ infestation and fetched average grain yield of $30.39 \mathrm{q} \mathrm{ha}^{-1}$. It was closely followed by the combination premix flubendiamide + buprofezin and hexaconazole with $3.16 \%$ average stem borer infestation. This study also corroborates the study of the above. Karthikeyan (2015) who elaborated that flubendiamide + buprofezin followed by combination of triazophos + 
tricylazole recorded lowest incidence of dead hearts $(0.53$ and $1.07 \%)$ and triazophos + tricylazole combination also recorded lowest incidence of white ear (3.90\%). Sheath blight incidence was low in triazophos + tricylazole and tricyclazole treated plots (19.00 and $25.63 \%$ ). The grain yield was highest in premix of flubendiamide + buprofezin $(3355 \mathrm{~kg}$ $\mathrm{ha}^{-1}$ ) treatment followed by tank mix of premix flubendiamide + buprofezin with hexaconazole (3268 $\mathrm{kg} \mathrm{ha}^{-1}$ ) and triazophos with hexaconazole $\left(3143 \mathrm{~kg} \mathrm{ha}^{-1}\right)$, triazophos with tricylazole $\left(3116 \mathrm{~kg} \mathrm{ha}^{-1}\right)$ treated plots. This study partially agree with the results of the above for management of YSB and paddy yield, showing that throughout the period premix of flubendiamide + buprofezin and its combination with hexaconazole and tricyclazole are the most effective treatments than triazophos and its combination with fungicides against YSB. The result of the present study representing hexaconazole to be the best fungicide against sheath blight differs with the results of the experiment of Karthikeyan (2015). According to Bhuvaneswari and Raju (2013) the insecticide, chlorantraniliprole in combination with fungicide, hexaconazole caused less incidence of stem borer. Prased et al., (2014) indicated that acephate was the best followed by the combination of pre-mix flubendiamide + buprofezin and flubendiamide with 3.50, 4.15 and 4.40 per cent of average YSB infestation; and 18.00, 16.37 and $16.27 \mathrm{q} \mathrm{ha}^{-1}$ average grain yields, respectively, were effective against YSB on semi deep water rice. The results of this experiment differs from the above studies revealing that pre-mix of flubendiamide + buprofezin and its combination with hexaconazole and tricyclazole are the most effective treatments than that of triazophos and its combination with fungicides against YSB. Rath (2011) showed that the combination product flubendiamide + buprofezin recorded less dead heart and white ear head which also corroborate our findings. Thus, the results reveal that there was no adverse impact on the efficacy of either the pre-mix of flubendiamide $4 \%+$ buprofezin $20 \%$ SC or triazophos $40 \% \mathrm{EC}$ due to their combination with hexaconazole $5 \% \mathrm{SC}$ or tricyclazole $75 \% \mathrm{WP}$ or vice versa confirming the compatibility of chemicals when used as a tank mix in the field.

\section{References}

Bhatnagar, A. 2004. Compatibility of pesticides against rice leaf folder and blast. Ann. Pl. Prot. Sci., 12: 208-10.

Bhuvaneswari, V. and Raju, S.M. 2013. Compatibility of fungicides and insecticides targeting sheath blight and major rice pests. J. Rice Res., 6: 64-71.

Catling, H.D., Islam, Z., and Pattrasudhi, R. 1987. Assessing yield losses in deepwater rice due to yellow stem borer, Scirpophaga incertulas (Walker), in Bangladesh and Thailand. Crop Prot., 6:20-27

Chatterjee, S., Dana, I., Gangopadhyay, C. and Mondal, P. 2017. Monitoring of yellow stem borer, Scirpophaga incertulas (Walker) using pheromone trap and light trap along with determination of field incidence in kharif rice, J. Crop and Weed, 13:15659.

Chatterjee, S., Gangopadhyay, C. and Roy, S.K. 2015. Management of rice insects by granular formulation of chlorantraniliprole along with foliar sprays of some new molecules. $J$. $P l$. Prot. Sci, 7: 6-13.

Chatterjee, S., Ghose, M.

and Gangopadhyay, C. 2016. Field screening of different rice entries against different insect-pests of rice during kharif season. Int. J. Agric., Env. Biotech., 9: 667-71.

Heinrichs E.A., Nwilene F E, Stout M J, Hadi 
B U R, Frietas T. 2017. Rice Insect Pests and Their Management. Cambridge: Burleigh Dodds Science Publishing, 277.

IRRI (International Rice Research Institute), 2013. Standard Evaluation System for Rice, $5^{\text {th }}$ Edition. International Rice Research Institute, Manila, Philippines, 65

(http://www.clrri.org/ver2/uploads/SES 5th_edition.pdf)

Karthikeyan, K. 2015. Compatibility studies of insecticide and fungicide molecules against major pests and sheath blight in rice. J. Rice Res., 8:71-75.

Manandhar, Hira Kaji, Ram Devi Timila, Sarala Sharma, Sharada Joshi, Shrinkhala Manandhar, Suk Bahadur Gurung, Sajal Sthapit, Epsha Palikhey, Anju Pandey, Balkrishna Joshi, Gyanu Manandhar, Devendra Gauchan, Devra Ivy Jarvis and Bhuwon Ratna Sthapit. 2016. A field guide for identification and scoring methods of diseases in the mountain crops of Nepal. Bioversiy International, 140-141.

Panda, N., Samalo, A.P., Patro, N. C. and
Reddy, T.G. 1976. Relative abundance of Lepidopteran stalk borer of rice in Bhubneswa. Indian Journal of Entomology. 3, 301-304.

Pasalu, I.C., Katti, G., Krishnamurthy, P., Subbarao, L.V., Reddy, C.S., Subaih, S.V., Krishnaih, N.V. and Prasad, J.S. 2005. Integrated pest management in rice In: Technical Bulletin, No. 15, Directorate of Rice Research, Hyderabad, P. 53.

Prasad, S.S., Gupta, P.K. and Mishra, J.P. 2014. Evaluation of certain new insecticides against yellow stem borer, Scirpophaga incertulas on semi deep water rice. Int. J. Curr. Microbiol. Appl. Sci., 3:736-40.

Prasad, S.S., Gupta, P.K. and Mishra, J.P. 2015. Field Studies on Compatibility of New Insecticides and Fungicides against Stem Borer and Leaf Blast under Semi Deep Water Rice Condition. Int. J. Res. Rev., 2:723-26 .

Rath, P.C. 2011. Testing of some new insecticides against insect pest of rice. J. Pl. Prot. Env., 8:31-33.

\section{How to cite this article:}

Chirasree Gangopadhyay and Sitesh Chatterjee. 2020. Pesticidal Compatibility against Yellow Stem Borer and Sheath Blight in kharif and Rabi Rice. Int.J.Curr.Microbiol.App.Sci. 9(11): 261-268. doi: https://doi.org/10.20546/ijcmas.2020.911.031 